\title{
The continuous expansion of citizen participation: a new taxonomy ${ }^{\ddagger}$
}

\author{
YANNIS THEOCHARIS* AND JAN W. VAN DETH \\ Mannheim Centre for European Social Research (MZES), University of Mannheim, Mannheim, Germany
}

\begin{abstract}
The repertoire of political participation in democratic societies is expanding rapidly and covers such different activities as voting, demonstrating, volunteering, boycotting, blogging, and flash mobs. Relying on a new method for conceptualizing forms and modes of participation we show that a large variety of creative, expressive, individualized, and digitally enabled forms of participation can be classified as parts of the repertoire of political participation. Results from an innovative survey with a representative sample of the German population demonstrate that old and new forms are systematically integrated into a multi-dimensional taxonomy covering (1) voting, (2) digitally networked participation, (3) institutionalized participation, (4) protest, (5) civic participation, and (6) consumerist participation. Furthermore, the antecedents of consumerist, civic, and digitally networked participation, are very similar to those of older modes of participation such as protest and institutionalized participation. Whereas creative, expressive, and individualized modes appear to be expansions of protest activities, digitally networked forms clearly establish a new and distinct mode of political participation that fits in the general repertoire of political participation.
\end{abstract}

Keywords: political participation; creative participation; digital media; protest; social networking sites

\section{Introduction}

Over the last few years, protest has been on the rise in every corner of the world. Such protests have often transformed major capital cities into battlegrounds for violent confrontations between citizens and the police. In 2014, however, over 4 months, students of the Technical University of Vienna decided to protest their government's decision to provide a multibillion package to bailout the Hypo Alpe Adria bank using a different and innovative form of urban protest. Disappointed that the petition calling for an official inquiry did not gather enough signatures, they designed a model city whose cost of building would have equalled that of the bailout, and set it up in Vienna's Karlsplatz, one of the city's main squares. 'Hypotopia', which would have been the sixth largest city in the country, not only

\footnotetext{
$\ddagger$ The original version of this article was published with footnotes containing important information to the article missing. A notice detailing this has been published and the error rectified in the online and print PDF and HTML copies.

*E-mail: yannis.theocharis@uni-mannheim.de
} 
captured the attention of thousands of citizens and tourists (many of whom assisted in its construction), but gained international media attention. A few months after that, thousands of Twitter users were using hashtags such as \#ifTheyGunnedMeDown and \#Dontshoot to refer to the portrayal of young minorities by mainstream media in the United States and to protest police violence in Ferguson, Missouri. Just before that, hundreds of undocumented teenagers in Houston who rarely had an opportunity to express or protest their hardships, used the hashtag \#ThisUndocumentedLife to share moments of their everyday lives with the wider public using Twitter and Instagram. While these events unfolded, hundreds of people in Europe have been holding, in The Guardian's words (Stoddart, 2014), the revolution in the palm of their hands, arming themselves with their weapon of choice in the war against urban wastelands: a seedbomb.

These examples do not only demonstrate the expansion of the repertoire of political participation (van Deth, 2001, 2014; Dalton, 2008b; Van Laer and Van Aelst, 2010). They reflect increasing tensions between voting and other well-established forms of political participation (such as being a party member, or signing a petition) as methods of engaging in politics on the one hand, and newer forms of engagement that may not fit classic definitions of political participation on the other. These new forms involve anything from public acts such as urban interventions, flash mobs, and deliberative experiments, to local or even private acts ranging from individual political podcasts, participatory theatre, and a multitude of other, 'creative', 'individualized', or 'self-expressive' acts (Smith, 2009; Micheletti and McFarland, 2011; Bennett and Segerberg, 2013; Chou et al., 2015; Kahne et al., 2015; Lee, 2015). As Bang and Sørensen (1999) suggest, this type of engagement often represents a way for citizens who are dissatisfied with the lack of impact their voice has in the political arena to participate in their own terms, in the political projects of their choice, and through the aspects of their identity they wish to express (Marsh and Akram, 2015: 524). Especially for young people, who have been shown to be disconnected from traditional politics and to be highly critical of politicians and the party-political system (Dalton, 2008b; Cammaerts et al., 2014; Sloam, 2014), new forms of participation - including selective, and even the 'action', of non-participation (Amnå and Ekman, 2014) - are becoming increasingly important. Relying on self-expressive rather than instrumental arguments, and often recognized and labelled by the participants themselves as social or non-political (a tendency often seen among people who are disillusioned with politics (Zuckerman, 2014)), these acts are not only hard to conceptualize, but often even difficult to recognize (van Deth, 2014). Consequently, it is complicated to assess their meaning for the development of, and impact on, the quality of democracy.

Although the importance of such acts for democratic politics is challenged (Gladwell, 2010; Milner, 2013; Morozov, 2013), arguments by various scholars (see Bang and Sørensen, 1999; Li and Marsh, 2008) that concepts related to new forms of participation are relevant and should be used more extensively, have been 
insufficiently considered. Instruments for measuring newer forms of participation remain largely absent from large-scale surveys, which persistently identify and measure political participation only through well established, but rather conventional participation repertoires. Despite allowing for comparability of participatory trends across time, this practice in survey research has been criticised for not capturing important political developments that may be occuring in parallel (Dunleavy, 1990). Social media-based and social media-enabled forms of participation are a case in point as, despite their increasing popularity among citizens (Smith, 2013), they have been met with reluctance and even suspicion by students of democracy and participation. It remains to be seen, argue Schlozman et al. (2012: 532), whether social networking sites and other such digital media platforms 'will encourage modes of online and offline participation as conventionally understood' or whether they will rather 'dilute the meaning of politically engaged citizenship'. Others do not even concede that such a transformation may emerge, dismissing these forms of engagement as 'non-participation' (Morozov, 2013: 5), and demeaningly depicting them with characterisations such as 'slacktivism' or 'clicktivism' (Morozov, 2009). Despite this disagreement, little has been done to analyse the similarities, differences, and relationships between old and newer forms of participation systematically.

The consequences of this lack of integration of new forms of participation, and the need for more precise and analytical conceptualizations that overcome the problems of narrow, existing ones focussing mainly on electoral and protest-related acts, is especially evident in debates about declining vs. changing political engagement among mass publics and its consequences for democracy. While some scholars consider the decline of voter turnout, party membership or demonstrating as signals for a deterioration of public engagement in many democracies (Pharr and Putnam, 2000; Milner, 2013), others are taking a more critical stance towards this view (O'Toole et al., 2003; Marsh and Akram, 2015). The continuous rise of new forms of participation, they argue, can be seen as sign of a vibrant democracy, that signals a 'second transformation' (Cain et al., 2003), whereby the meaning of politically engaged citizenship and the concept of participation is changing (Dalton, 2008a; van Deth, 2014; Marsh and Akram, 2015). The crucial question, then, is how to integrate both new and old forms of participation systematically into a general repertoire of political participation in ways that are conceptually meaningful and can allow for a consistent measurement of the phenomenon.

Whether we agree upon calling the large variety of continuously emerging but seemingly unpolitical expressive and creative acts as forms of political participation, is important for at least two reasons. First and most importantly, assessments of the quality of democracy depend on the question whether new acts are conceptualized as political; by accepting them as political a positive assessment becomes more likely. Second, revised conceptualizations of participation provide an opportunity to trace changing political orientations of groups that are notoriously marginalized from institutional politics: much of the literature shows, for example, that if we are willing to consider the very extensive use of online participation by young people 
(Henn et al., 2005; Marsh et al., 2007; Smith, 2013; Xenos et al., 2014), we will be able to better understand behavioural changes among a group traditionally disengaged from politics, that stretch beyond the conventional image of an apathetic youth. Failing to measure and conceptualize new forms of participation, therefore, may result in seriously underestimating political involvement of certain segments of the population.

This study advances the understanding of emerging new forms of political participation by systematically establishing their conceptual and empirical relevance within the broader repertoire of participation. Despite the widespread references to expressive, creative, and other seemingly non-political acts in scholarly work, there has been little effort to determine whether such acts fit the traditional or expanded concepts of political participation and how to integrate them into the broader structure of political participation. Moreover, with the exception of political consumerism, no studies have empirically established whether citizens perceive acts that do not fit traditional definitions of participation, not simply as alternative participatory avenues, but also as legitimate political acts. Building on recent efforts to improve conceptualizations of political participation (Fox, 2013; Gibson and Cantijoch, 2013; van Deth, 2014; Theocharis, 2015), the study expands these debates by making three contributions to the literature: (a) it offers an integrated method for measuring old and new forms of participation; (b) it provides systematic empirical evidence as to how new forms of participation such as creative, selfexpressive, individualized, and digitally networked acts fit within a general taxonomy of participation, and (c) it empirically assesses the main antecedents of various traditional and new modes of political participation in order to illustrate how they co-exist alongside each other as important components of a politically active citizenship.

\section{Conceptualizing political participation}

Perhaps the most common definition of political participation is provided by Verba and Nie according to which political participation is understood as 'those activities by private citizens that are more or less directly aimed at influencing the selection of governmental personnel and/or the actions they take' (1972: 2). Verba and Nie organized participation into four broad modes: voting, campaign activity, cooperative activity, and citizen-initiated contacts. Placing particular emphasis on the idea of participation as a form of action, Kaase and Marsh (1979) added further 'unconventional' forms of participation (such as attending demonstrations and joining boycotts), opening up the possibilities for wider definitions. Besides, political participation gradually became relevant in areas that would be considered private, social, or economic in earlier times (Brady, 1999; van Deth, 2001; Rowe, 2015), most clearly blurring the boundaries between political and civic participation (Macedo et al., 2005). As a result, very broad definitions have been proposed depicting political participation as 'any dimensions of social activity that are either 
designed directly to influence government agencies and the policy process, or indirectly to impact civil society, or which attempt to alter systematic patterns of social behavior' (Norris, 2002: 16). Such broad definitions - accompanied, paradoxically, with rather narrow ways of operationalizing and measuring participation in large-scale empirical studies - led to calls for renewing our understanding of participation (Fox, 2013). Surprisingly, apart from their use in specialized projects and case studies, creative, self-expressive, individualized, and digitally networked acts of participation are still seen with suspicion by many scholars, and are thus often left out from major surveys.

Starting at least with Verba and Nie's seminal definition cited above, political participation has four minimal definitional features: (i) participation is an activity, (ii) it is voluntary and not ordered by a ruling class or obliged under some law, (iii) it refers to people in their role as non-professionals or amateurs, and (iv) it concerns government, politics, or the state (cf. van Deth, 2014). Thus, following this elementary definition of political participation, any voluntary, non-professional activity concerning government, politics, or the state is a specimen - a form - of political participation. Several forms of participation sharing some feature are called a mode or type of participation, and we adapt the term repertoire of political participation (from Tilly's 'repertoire of contention') as a broader term that unites all available forms (and modes) of participation into a broader framework of all political engagement activities (or 'tactics') (cf. Tilly, 1995: 41-48). Although these four definitional criteria make certain specimens of political behaviour easy to identify (such as casting a vote or signing a petition) or to exclude (such as repairing your bike or lending a pound of sugar to your neighbour), other acts are not as easy to detect. Is, for example, creating and planting a seedbomb in one's neighbourhood a form of political participation? Is the act of circulating on Twitter a picture of yourself, embedding the hashtag \#ThisUndocumentedLife or \#Dontshoot, a form of political participation? To what extent does personalizing a pair of NIKE shoes with the word 'sweatshops' inscribed on them fit definitions of participation that do not consider corporations as their targets (McCaughey and Ayers, 2003)? Does the global reach of feminist groups that emerged out of local stay-at-home-mums communities (Rowe, 2015) sharing interests, affinities, and identities that have been traditionally confined to the private realm (Young, 1989) amount to political participation? And if these actions indeed are forms of political participation how, then, do they fit into the general repertoire of participation? ${ }^{1}$

\footnotetext{
${ }^{1}$ It is important to note here that although in this paper we do not consider intentional lack of participation due to our focus on manifest "activities" (as per Parry et al., 1992, p.16), non-participation is a stance which, as O’Toole and colleagues (2003) argue, can under certain circumstances excert significant political power - making the identification of political participation an even more complex affair (Author 2014). There is convincing evidence from studies employing both qualitative and quantiative approaches showing that non-participation is a complex phenomenon that has received little careful attention in existing scholarship, and that what is sometimes thought of as passivity can be a stance with several different dimensions and very far from political apathy (O’Toole et al., 2003, p.350; Amnå \& Ekman, 2014, p.268).
} 
Proponents of restricted definitions - such as the one provided by Verba and Nie (1972) - would answer an emphatic 'no' to these questions. Others, accepting definitions that are broader in scope (such as that of Norris) would be less reluctant to accept them as forms of political participation. At this point an impasse is reached, and the two streams of scholars take each their own way, following their own interpretation of participation and, inevitably, producing different assessments of the democratic health of contemporary societies.

A fresh approach can be based on the development of an operational definition of political participation specifying the exact properties that are required to determine its existence. Following van Deth (2014) we use a systematically developed set of decision rules to answer the question whether a specific phenomenon can be considered as political participation. The schema follows a hierarchically ordered classification, whereby each subgroup is 'defined by the specification of necessary and sufficient conditions of membership' (Hempel, 1965: 138). For a minimalist definition Verba and Nie's criteria are used, and so an act of political participation should be carried out voluntarily by a (politically) non-professional citizen taking place within the realm of politics, government or the state. Second, a targeted definition would fulfil the same requirements even if it is not taking place within the locus of politics, government, or the state, but is rather targeted towards them or towards a community problem. If the target is not clear either, then a look at the political context or the motives of the participant should provide a clear indication about the act's political nature. The advantage of following these decision rules is not only that we can distinguish between political acts that fit into definitions with stricter or loser requirements, ${ }^{2}$ but also that we can systematically exclude those who do not meet the definitional requirements.

Using these definitional parameters, we can straightforwardly classify the participatory examples mentioned at the beginning of this article. Assisting in the building of 'Hypotopia' is an activity carried out voluntarily by non-professional citizens that, as a non-institutionalized act, takes place outside the locus of politics, government and the state, but clearly targets them. Therefore 'Hypotopia' qualifies as political participation, specifically as a specimen of a targeted definition. Posting a photo of oneself on Twitter embedding the hashtag \#Dontshoot does not conform to the minimalist definition as it does not take place within the locus of politics, government, or the state. Yet, it clearly is a form of political participation not only because it is aimed at a community problem (namely police violence and race relations in Ferguson), but also because the platform enables the user to frame the context as political by using the relevant protest hashtag \#Dontshoot.

If the first step for understanding the expansion of political participation is to systematically conceptualize emerging forms that verge on the unpolitical, the

\footnotetext{
2 This extends from acts that belong only within the locus of politics/government/state (such as voting) to acts that are classified as political due to the circumstances under which they take place (such as a using a hashtag to post a personal photo-statement against police violence in Ferguson).
} 
immediate second step should be to measure such acts that extend beyond the long-established close-ended questions about electoral, party related, and protest participation used in most studies.

\section{Measuring political participation}

To empirically investigate the place of new forms of participation within the broader repertoire of political participation, develop a new way to measure them, and focus on the relationships between distinct forms, we decided to restrict our attempts to a single national context: Germany. This country is not only the largest democracy in Europe; it also exhibits a number of societal features that make it an interesting and distinct case for our endeavour. After the end of the Second World War, and especially after the early 1970s, Germany has experienced one of the larger shifts in its social and political culture, exhibiting, for example, one of the highest increases in gender equality in Europe and probably the largest swing towards self-expressive (or 'emancipative') values than any other country (Welzel, 2013: 99). In addition, Germany is classified as the country with one of the most assertive political cultures in the world (Welzel, 2013) and thus offers a case in which engagement in new forms of political participation should be a prevalent rather than a marginal phenomenon among the population. This allows us to observe structural similarities and differences between old and new forms of engagement. At the same time, Germany has one of the lowest levels of social media penetration in Europe (Kemp, 2014). Granted that it also has one of the highest levels of internet penetration in Europe, lack of social media ownership is probably related to heightened privacy concerns associated with postwar experiences; it is thus the outcome of choice and not of lack of possibility for Germans to own a social media account. This makes digitally networked participation (DNP; Theocharis, 2015) - the most popular example of a new form of engagement - less likely to be encountered as a mode of participation than in most other Western societies. At the same time, it also makes it a very important mode to identify within the broader repertoire of participation and to compare with both older and other new modes of engagement. From this point of view, it can give us a sense of how things are shaped in European states that have a much more open attitude towards digital media.

We designed a short survey for a representative sample of the German population (age 18 and older). Telephone interviews (CATI) were carried out between 17 April and 9 May 2015, with an average duration of 8.4 minutes. ${ }^{3}$ A total of 1004 interviews are available for analysis (response rate $20.2 \%$ ). The question wording of the items on political participation is included in the supplementary material (Appendix B).

\footnotetext{
${ }^{3}$ The contacting strategy was based on the widely used GESIS-certified Gabler-Häder-Design that is not limited to landlines but also includes mobile phones.
} 


\section{Measurement procedure}

For a long time survey researchers have measured political participation by going through a list of specific forms of participation (e.g. voting, demonstrating, contacting politicians) and asking for each of them whether the respondent has used it. The continuous expansion of the repertoire of participation resulted in corresponding expansions of these lists, but - as mentioned - many large-scale projects (WVS: World Values Survey; ESS: European Social Survey; EVS: European Values Study; EES: European Election Study; etc.) restrict the number presented to the respondents to five or six major forms of participation. In addition, the scope of introductory sentences used has been broadened to avoid a concentration on government or electoral politics only. Finally, a time frame is included in many instruments nowadays in order to avoid that a single action would depict a citizen as an activist for her entire life.

In order to measure political participation, we first compiled a list of 13 common forms of participation, ranging from voting in the last election to demonstrating and boycotting products for political or ethical reasons (see supplementary material). Our study also makes the first step in measuring several manifestations of DNP in Germany expanding the list with three items covering the most common - and consistently used by the Pew Research Centre - variants of activities on digital media dealing with social or political issues: posting or sharing links, commenting, and encouraging other people to take action (Smith, 2013). Because we wanted to avoid any suggestion about the nature, direction, or goal of all these actions, the introductory sentence for the total set of questions was restricted to 'During the last twelve months, have you done any of the following: ...' with response categories 'yes', 'no', and 'no answer/refused to say'.

The measurement of newer, creative and individualized forms of political participation is a more challenging task as, by definition, these forms are very difficult to measure with straightforward questions ('Did you do anything in the last twelve months that could be considered a form of political participation?'). Following the hierarchically structured nature of the conceptualization presented in the previous section we presented an open-ended question on new forms of participation immediately after going through the list of 16 forms of participation. In the same vein as O'Toole and colleagues (2003: 350), we intented to - as much as possible - enable our respondents to freely relate to politics as an expressive activity they may have been engaged in. Thus, we placed the open question at the very end of the survey, expecting that the tendency of a respondent to consider 'something else' that could more freely or loosely be associated with political participation, would be relatively higher after she went through a list of more or less commonly known political acts. Presumably, because all kinds of actions had already been mentioned, the respondent would also grasp what we were not looking for as a response to the additional question. The following question was thus included in our survey as a 17 th item:

In Berlin a group of people planted flowers in abandoned sites without permission, in order to make their neighbourhood more beautiful; In Vienna hundreds helped 
creating a miniature model of a city that could have been built instead of bailing out banks. In Ferguson, thousands shared photos on social media to protest the shooting of a young black man by a white policeman. Many other examples of such expressive actions can be thought of and these are only three examples.

During the last twelve months, have you been engaged in any such actions to express your political or social views or concerns?

All respondents confirming this last question were asked: 'what did you do?' and the interviewer wrote down up to three responses.

\section{Coding procedure}

A total number of 101 respondents $(10.1 \%)$ indicated that they indeed had been engaged in actions aimed at expressing political or social views or concerns similar to the ones mentioned in the introductory text. Of these respondents 90 mentioned an action or cause (remainders 'don't know' or refusals), whereas 16 respondents mentioned two, and four even three actions or causes. As a result the interviewers wrote down 110 actions or causes. Typical answers are as follows:

- 'Marketplace beautification with flowers'

- 'Planting my street'

- 'Spread seed bombs across vacant land to beautify the area'

- 'Commitment to the preservation of a community garden project'

- 'Flower planting and paper collection to beautify the area'

- 'Privately planted flowers and grave maintenance, everything paid for itself, alone and unaided'

- 'Flowers laid down for refugee victims in the Mediterranean'

- 'Care pathways'

- 'To beautify the city; cleaning action on a voluntary basis'

- 'Action to build a memorial against genocide for descendants of the Armenians'

- 'Panel discussion on equality of homosexuals'

- 'Performing games in protest against too little separation of church and state in Germany'

- 'Dance for the use of public space'

- 'Acts of civil disobedience'

- 'Balloon action about lesbian and gay rights'

- 'Regular writing letters to the editor'

- 'Rehabilitation project of child soldiers'

The number and variety of these responses reflect the expected variety of the actions and causes people nowadays use for political purposes. Yet, many answers refer to urban gardening and city beautification with flowers and seeds scattered on public spaces. This frequency shows the prominent position of these actions among the 
newer forms of participation. ${ }^{4}$ Furthermore, some people mentioned demonstrations or signature actions despite the fact that these forms had been clearly included in the list of actions presented to them only a few seconds before.

In order to make the actions mentioned accessible for quantitative analyses, a coding and recoding procedure was developed including two steps. First, all actions mentioned that were already unmistakably covered by one of the 16 closed questions were deleted from the list of additional forms of participation, but coded under the correct form. For instance, the answer 'Petition to ban dangerous dogs' was not coded as an additional form of participation, but recoded under the item 'Signed a petition'. Second, all general references to 'actions' or 'protests' were coded as additional modes of participation, because the respondents already had the opportunity to include such actions under one or more of the previous items. For instance, the answer 'Action roundtable for refugees' apparently is an additional form of participation and was coded as such; the same applies to answers whose specific form is less clear, such as 'Local action against Nazis' or in case a further clarification is refused by the respondent. Only if the respondent confirms an additional activity in general, but does not know how to specify it, the response is not considered to be an expression of partaking in an additional form of participation. As a result of this procedure, a new variable was constructed for these additional forms of political participation ('other') with 52 (5.2\%) of the respondents having made use of it.

\section{Descriptive results}

Figure 1 shows the relative number of people involved in each of the 17 forms of participation used in this study. ${ }^{5}$ The general pattern of these frequencies is in line with the results of similar studies in Germany and many other advanced democracies: while voting still is, by far, the most used form of participation, other activities involving party work and political donations are at the very end of the distribution with only tiny parts of the population using these forms (Gabriel and Völkl, 2005; Teorell et al., 2007). Not surprisingly, the percentage of people using new forms of participation (designated as 'other') is also limited (although no less popular than working for a party or candidate). Many more substantial parts of the population have been involved in activities such as signing a petition or boycotting products. All three digitally networked forms are in the lower part of the graph, and have been done by modest percentages of the population only (11-15\%).

\footnotetext{
${ }^{4}$ Since urban gardening was mentioned explicitly in the introductory text a slight over-reporting cannot be excluded. However, none of the other examples used in the introduction were mentioned frequently by the respondents so the effect is probably modest.

${ }^{5}$ All descriptive results presented here are based on computations weighted with dual-frame design weights taking into account the fact that we have a combination of fixed and mobile samples, resulting in composite selection probabilities.
} 


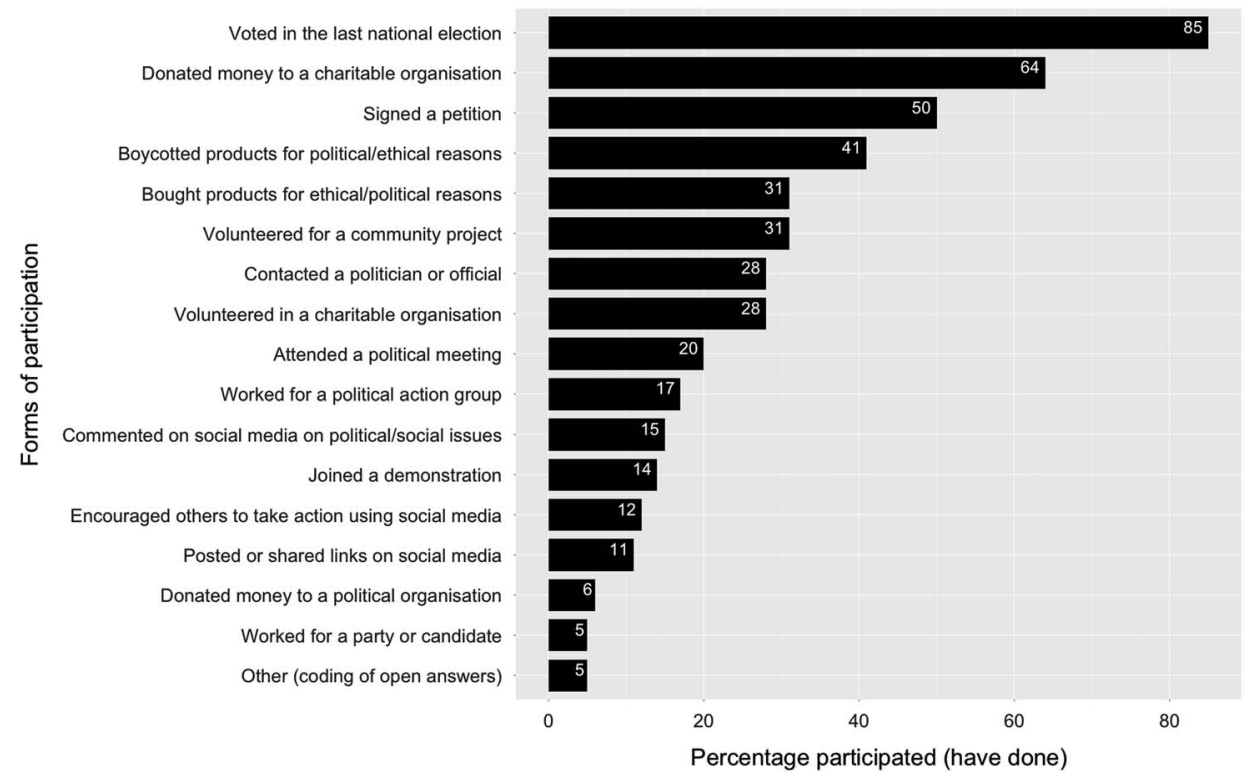

Figure 1 Frequencies of forms of participation. Cases weighted by design weight (normalized for sample size).

With the large number of participation forms mentioned, it does not come as a surprise that only very few Germans $(4 \%)$ have not been involved in any of the activities mentioned. Similarly, only very few people $(8 \%)$ indicate that they have used 10 or more of these forms. The average number of forms used is 4.64 (std. dev. $=2.97)$ - if casting a vote in the last national elections is not taken into account this figure drops to 3.79 forms (std. dev. $=2.88$ ).

\section{Modes of political participation and their main antecedents}

Do new forms of participation establish a distinct mode of political participation? In order to answer this question empirically, internal and external validation strategies are applied here. First, the internal strategy focusses on the latent structure for the 17 items used to measure distinct forms of participation. A structure underlying these responses should present a conceptually convincingly taxonomy of main modes of political participation. Second, the external strategy is based on the idea of 'nomological networks' (Cronbach and Meehl, 1955: 290), presuming that similar concepts should play the same role or perform the same function in broader explanations. For our modes of participation, this implies that major antecedents should all show well-known relationships; that is, individual resources, and attitudes such as value orientations, satisfaction with democracy and support of active citizenship should be relatively strongly correlated with distinct modes of political participation. 


\section{Internal validation: a taxonomy of political participation}

A principal component analysis (PCA) of the 17 items for political participation reveals a clear latent structure with five components. Two items, however, do not fit into this structure; neither 'voting in the last national election' nor 'donating money to a charitable organization' reache satisfactory loadings in the rotated component matrix. Whereas many studies have shown the special character of voting as a distinct form of political participation (see, for instance, Parry et al., 1992: 50-52), donating money apparently does not belong to the repertoire of political participation either. Given the dichotomous nature of the items, however, we also performed a second PCA based on tetrachoric correlations. Yet, a positive definite matrix could only be obtained by deleting 'voting' from the analysis. Although four components can be derived with an eigenvalue $>1.0$, inspecting the explained variances for the distinct components indicates that five components provide a more appropriate solution (the fifth component showing an eigenvalue of 0.998). The two PCAs - based on product-moment and tetrachoric correlations - provide exactly the same results, with 'voting' and 'donating money' as the two items which do not fit clearly in the configurations obtained. Table 1 shows the structure based on tetrachoric correlations. ${ }^{6}$

The five consistent components revealed by the analyses together shape a taxonomy of political participation with (1) the four forms dealing with parties, politicians, and political meetings indicating a mode called 'Institutionalized participation', (2) the three forms of digitally networked activities representing a mode called 'DNP', (3) four forms of protest participation including the additional coded activities ('other') representing a mode called 'Protest', (4) two items on 'Volunteering', and (5) two items on 'Consumerist participation'. These initial analyses are already sufficient to reach two important conclusions. First, DNP, perhaps the most popular and most debated of the emerging forms of participation, is very clearly not an expansion of an existing mode of participation, but a more fundamental expansion of the repertoire with a distinct mode of participation. Second, creative, expressive, and individualized forms of participation appear to play a less innovative role: they broaden the already available protest dimension and are, in this way, well integrated in the existing repertoire.

A suspicious reader may remain unconvinced that DNP is actually a mode of participation with clearly identifiable forms, and argue that we may be simply capturing general, online activities that have an offline equivalent, and not necessarily activities enabled by social media tools such as microblogs and social networking sites. Previous research, however, provides grounds to presume that not

\footnotetext{
${ }^{6}$ Results of confirmatory factor analyses are very similar to the results of the principal components analyses presented here. Apparently the existence of five distinct dimensions underlying the 17 items does not depend on the technique chosen or the distributional properties of the data. Since the results of the component analyses can be presented straightforwardly we restrict the presentation to this latent structure here.
} 
Table 1. Structure of political participation (PCA based on tetrachoric correlations; coefficients $>0.40$ )

\begin{tabular}{|c|c|c|c|c|c|}
\hline & $\begin{array}{l}\text { Institutionalized } \\
\text { participation }\end{array}$ & DNP & Protest & Volunteering & $\begin{array}{l}\text { Consumerist } \\
\text { participation }\end{array}$ \\
\hline Worked for a party or candidate & 0.864 & & & & \\
\hline $\begin{array}{l}\text { Donated money to a political } \\
\text { organization }\end{array}$ & 0.808 & & & & \\
\hline Attended a political meeting & 0.795 & & & & \\
\hline Contacted a politician or official & 0.670 & & & & \\
\hline $\begin{array}{l}\text { Commented on social media on } \\
\text { political/social issues }\end{array}$ & & 0.906 & & & \\
\hline $\begin{array}{l}\text { Posted or shared political links on } \\
\text { social media }\end{array}$ & & 0.859 & & & \\
\hline $\begin{array}{l}\text { Encouraged other people to take } \\
\text { action using social media }\end{array}$ & & 0.809 & & & \\
\hline Signed a petition & & & 0.809 & & \\
\hline Worked for a political action group & & & 0.728 & & \\
\hline Joined a demonstration & & & 0.527 & & \\
\hline Other (coded open answers) & & & 0.524 & & \\
\hline $\begin{array}{l}\text { Volunteered in a charitable } \\
\text { organization }\end{array}$ & & & & 0.872 & \\
\hline Volunteered for a community project & & & & 0.838 & \\
\hline $\begin{array}{l}\text { Bought products for political/ethical } \\
\text { reasons }\end{array}$ & & & & & 0.895 \\
\hline $\begin{array}{l}\text { Boycotted products for political/ } \\
\text { ethical reasons }\end{array}$ & & & & & 0.844 \\
\hline $\begin{array}{l}\text { Donated money to a charitable } \\
\text { organization }\end{array}$ & & & & & \\
\hline
\end{tabular}

DNP = digitally networked participation.

Varimax with Kaiser Normalization; matrix of tetrachoric correlations for 17 items not positive definite, therefore 'voting' is deleted from the analyses. Explained variance: $67 \% ; N=1004$.

only certain online acts in general (Oser et al., 2013: 98) but DNP in particular, establishes a distinct mode of political participation. In one of the few studies examining whether online participatory acts are not only independent from offline acts, but also from other online acts that may effectively be online replications of offline acts, Gibson and Cantijoch (2013: 714) show that online forms of engagement that 'take a more active collective, and networked quality in the online environment' are indeed independent of offline and other online acts, concluding that 'there is evidence that the medium matters'. The results of our analyses corroborate this finding by showing that three quintessentially digitally enabled acts cluster together under the umbrella of DNP and establish a distinct mode of participation within the general repertoire.

For each of the five distinct modes of political participation, levels of participation are computed based on additive scores corrected for the number of each item (resulting in standardized scales $0-1$ ). The percentages of those who have engaged 


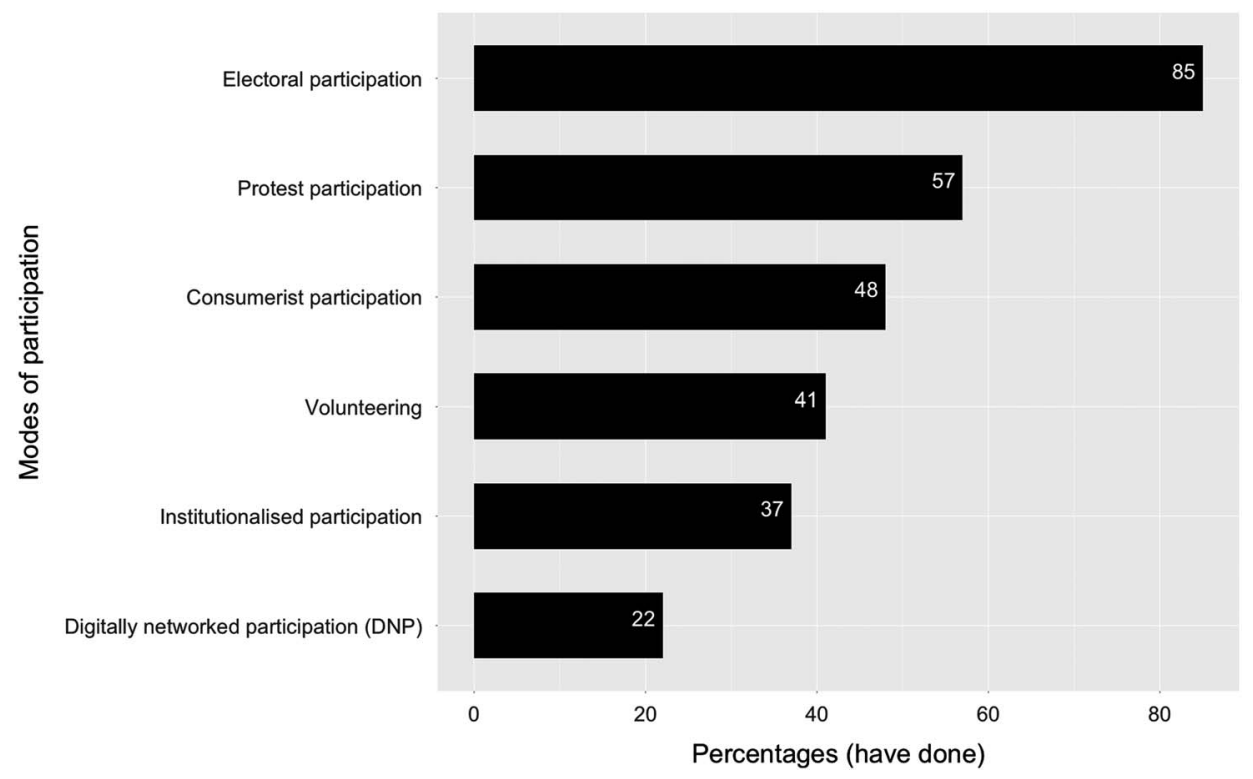

Figure 2 Levels of participation for distinct modes. Cases weighted by design weight (normalized for sample size).

in each one of those five activities, as well as in electoral participation, are shown in Figure 2. Perhaps the most important insight offered by this figure is that the highest levels of non-electoral participation are observed not only in protest activities, but also in the two modes of participation which lack a clear political connotation (consumerism and volunteering). This finding adds evidence to a growing literature demonstrating the popularity of non-institutionalized, community-oriented and lifestyle-driven participation, as opposed to engagement through traditional political avenues such as political parties (Dalton and Wattenberg, 2000; Stolle et al., 2005; Zukin et al., 2006). DNP, on the other hand, shows the lowest level of involvement.

Furthermore, the six modes of participation are all moderately but positively correlated with each other (bivariate product-moment correlations ranging from 0.09 for electoral participation and protest, to 0.33 for protest and institutionalized participation). Apparently, the modes of participation are not used separately by specific parts of the population - being involved in one mode of participation clearly increases the chances of using other modes too. This finding echoes previous research showing that, for those who participate in politics, the new modes investigated here do not replace older modes of participation but rather complement citizens' repertoires (Norris, 2001; Van Laer and van Aelst, 2010; Oser, 2016). The single exception of this picture is provided by the relationship between casting a vote and engaging in DNP: of the 15 bivariate correlations for the six modes of participation only this coefficient is very modest and negative $(-0.014)$. Besides, only this estimate does not reach an acceptable level of statistical significance $(P<0.01$; two-tailed). This result could be 
due to the fact that this finding concerns the relationship between the most frequently and the least frequently used modes of participation, thus reducing the chances to obtain a positive correlation. However, also non-parametric correlation coefficients $(\tau$-b and $\rho)$ for this relationship are very modest but positive - more importantly they are also non-significant $(P<0.01$; two-tailed). All these estimations suggest that voting and DNP probably do not come together; that is, being involved in one of these two modes of participation does not influence the chances of using the other mode too.

\section{External validation: antecedents of political participation}

Although extant research has long established the main antecedents of political participation, less is known about the extent to which newer modes share similar predictors. If we are dealing with similar concepts, then structural similarities between the 'nomological networks' for various modes of political participation should be evident. To this purpose, given the distributional properties of the additive participation scales, we first recoded all dependent variables as binary variables (except from voting which is already binary), each indicating whether a respondent had made use of at least one of the forms of participation belonging to a certain mode (1) or not (0). Subsequently, identical logistic regression models are estimated for all six modes of political participation (sensitivity tests with count models can be found in Appendix A of the supplementary material). Scores for each mode of participation are regressed in two steps: first using only individual resources (gender, education, age, and age squared) ${ }^{7}$ and, subsequently, adding typical attitudinal variables predicting participation (values, satisfaction with democracy, and left-right self-placement), as well as support for a relevant norm of citizenship (being active in politics) (Dalton, 2008a). ${ }^{8}$ It should be noted that the models we estimated cover many of the most important antecedents of participation (Milbrath and Goel, 1977; Verba et al., 1995; Brady, 1999), but remain underspecified as we do not aim to offer complete empirical explanations for the use of various modes of participation here. Instead, our aim is to explore the structural relationships between each of the six modes of participation discerned and a common set of major antecedents in order to obtain evidence of common understandings.

The regression results shown in Table 2 corroborate findings from previous research. Resources (see the first models for each mode of participation) are, give or take, significant antecedents of participation. Higher education is consistently statistically significant in every model, while men have a significantly higher probability of engaging in DNP, institutionalized and protest acts, but not in consumerist acts in which women have a higher probability to be engaged. That women are more likely to be involved in consumerist activities has been corroborated in a number of studies on

\footnotetext{
${ }^{7}$ Although all findings hold with the inclusion of the income variable, given the high proportion of items missing from this variable $(25 \%)$ we chose not to include income in the final models. All models including income can be found in the Appendix, Table A1.

${ }^{8}$ A detailed elaboration on the measures, as well as descriptives are provided in Appendix C.
} 
Table 2. Antecedents of six modes of political participation (Logistic regressions)

\begin{tabular}{|c|c|c|c|c|c|c|c|c|c|c|c|c|}
\hline & \multicolumn{2}{|c|}{ DNP } & \multicolumn{2}{|c|}{ Institutionalized } & \multicolumn{2}{|c|}{ Consumerist } & \multicolumn{2}{|c|}{ Protest } & \multicolumn{2}{|c|}{ Volunteering } & \multicolumn{2}{|c|}{ Voting } \\
\hline & (1) & (2) & (3) & (4) & (5) & (6) & (7) & (8) & (9) & (10) & (11) & (12) \\
\hline Gender & $\begin{array}{c}-0.284 \\
(0.160)\end{array}$ & $\begin{array}{l}-0.359 \\
(0.169) *\end{array}$ & $\begin{array}{l}-0.643 \\
(0.135)^{* * *}\end{array}$ & $\begin{array}{l}-0.750 \\
(0.148) * * *\end{array}$ & $\begin{array}{l}0.533 \\
(0.137)^{* * *}\end{array}$ & $\begin{array}{l}0.493 \\
(0.147) * * *\end{array}$ & $\begin{array}{c}-0.170 \\
(0.133)\end{array}$ & $\begin{array}{l}-0.280 \\
(0.142)^{*}\end{array}$ & $\begin{array}{c}-0.147 \\
(0.132)\end{array}$ & $\begin{array}{c}-0.191 \\
(0.139)\end{array}$ & $\begin{array}{c}-0.168 \\
(0.189)\end{array}$ & $\begin{array}{c}-0.202 \\
(0.209)\end{array}$ \\
\hline Education & $\begin{array}{l}1.320 \\
(0.312)^{* * *}\end{array}$ & $\begin{array}{l}1.345 \\
(0.334) * * *\end{array}$ & $\begin{array}{l}1.281 \\
(0.259)^{* * *}\end{array}$ & $\begin{array}{l}1.154 \\
(0.282)^{* * *}\end{array}$ & $\begin{array}{l}2.034 \\
(0.262) * * *\end{array}$ & $\begin{array}{l}1.835 \\
(0.280)^{* * *}\end{array}$ & $\begin{array}{l}1.215 \\
(0.252)^{* * *}\end{array}$ & $\begin{array}{l}1.002 \\
(0.269)^{* * * *}\end{array}$ & $\begin{array}{l}1.340 \\
(0.253)^{* * *}\end{array}$ & $\begin{array}{l}1.158 \\
(0.267) * * *\end{array}$ & $\begin{array}{l}1.835 \\
(0.363)^{* * *}\end{array}$ & $\begin{array}{l}1.403 \\
(0.399)^{* * * *}\end{array}$ \\
\hline Age & $\begin{array}{l}-2.728 \\
(2.101)\end{array}$ & $\begin{array}{l}-3.030 \\
(2.233)\end{array}$ & $\begin{array}{c}3.570 \\
(1.717) *\end{array}$ & $\begin{array}{c}3.484 \\
(1.857)\end{array}$ & $\begin{array}{l}7.890 \\
(1.793) * * *\end{array}$ & $\begin{array}{l}7.250 \\
(1.902) * * *\end{array}$ & $\begin{array}{c}3.630 \\
(1.669) *\end{array}$ & $\begin{array}{c}2.653 \\
(1.776)\end{array}$ & $\begin{array}{c}1.042 \\
(1.657)\end{array}$ & $\begin{array}{c}1.095 \\
(1.738)\end{array}$ & $\begin{array}{c}5.208 \\
(2.289) *\end{array}$ & $\begin{array}{l}6.842 \\
(2.485) * *\end{array}$ \\
\hline Age squared & $\begin{array}{c}-0.174 \\
(2.502)\end{array}$ & $\begin{array}{c}-0.111 \\
(2.662)\end{array}$ & $\begin{array}{l}-3.530 \\
(1.897)\end{array}$ & $\begin{array}{r}-3.638 \\
(2.060)\end{array}$ & $\begin{array}{l}-9.949 \\
(2.021)^{* * *}\end{array}$ & $\begin{array}{l}-9.436 \\
(2.148)^{* * * *}\end{array}$ & $\begin{array}{l}-4.996 \\
(1.847)^{* * *}\end{array}$ & $\begin{array}{l}-4.046 \\
(1.965) *\end{array}$ & $\begin{array}{c}-1.268 \\
(1.836)\end{array}$ & $\begin{array}{c}-1.516 \\
(1.931)\end{array}$ & $\begin{array}{c}-2.871 \\
(2.683)\end{array}$ & $\begin{array}{c}-4.542 \\
(2.911)\end{array}$ \\
\hline Values: mixed & & $\begin{array}{l}-0.227 \\
(0.396)\end{array}$ & & $\begin{array}{c}0.159 \\
(0.376)\end{array}$ & & $\begin{array}{c}0.354 \\
(0.348)\end{array}$ & & $\begin{array}{l}-0.012 \\
(0.323)\end{array}$ & & $\begin{array}{c}0.342 \\
(0.344)\end{array}$ & & $\begin{array}{l}-0.560 \\
(0.481)\end{array}$ \\
\hline Values: postmaterialist & & $\begin{array}{c}0.306 \\
(0.396)\end{array}$ & & $\begin{array}{c}0.676 \\
(0.378)\end{array}$ & & $\begin{array}{l}0.928 \\
(0.352) * *\end{array}$ & & $\begin{array}{c}0.533 \\
(0.329)\end{array}$ & & $\begin{array}{c}0.409 \\
(0.348)\end{array}$ & & $\begin{array}{c}-0.502 \\
(0.492)\end{array}$ \\
\hline $\begin{array}{l}\text { Satisfaction with } \\
\text { democracy }\end{array}$ & & $\begin{array}{l}-0.763 \\
(0.392)\end{array}$ & & $\begin{array}{c}0.286 \\
(0.344)\end{array}$ & & $\begin{array}{c}0.364 \\
(0.348)\end{array}$ & & $\begin{array}{c}0.191 \\
(0.335)\end{array}$ & & $\begin{array}{c}0.524 \\
(0.330)\end{array}$ & & $\begin{array}{l}1.646 \\
(0.475)^{* * *}\end{array}$ \\
\hline Left/right placement & & $\begin{array}{l}-0.326 \\
(0.442)\end{array}$ & & $\begin{array}{l}-0.029 \\
(0.371)\end{array}$ & & $\begin{array}{l}-1.243 \\
(0.371)^{* * *}\end{array}$ & & $\begin{array}{l}-0.316 \\
(0.353)\end{array}$ & & $\begin{array}{l}-0.122 \\
(0.350)\end{array}$ & & $\begin{array}{l}-0.481 \\
(0.526)\end{array}$ \\
\hline $\begin{array}{l}\text { Good citizen norm: active } \\
\text { in politics }\end{array}$ & & $\begin{array}{c}1.094 \\
(0.390)^{* * *}\end{array}$ & & $\begin{array}{l}2.293 \\
(0.348) * * *\end{array}$ & & $\begin{array}{l}0.894 \\
(0.328)^{* *}\end{array}$ & & $\begin{array}{l}1.246 \\
(0.317)^{* * *}\end{array}$ & & $\begin{array}{l}1.028 \\
(0.315)^{* *}\end{array}$ & & $\begin{array}{l}2.185 \\
(0.449) * * *\end{array}$ \\
\hline Constant & $\begin{array}{l}-0.828 \\
(0.311) * *\end{array}$ & $\begin{array}{l}-0.756 \\
(0.616)\end{array}$ & $\begin{array}{l}-1.408 \\
(0.288)^{* * *}\end{array}$ & $\begin{array}{l}-3.163 \\
(0.576)^{* * *}\end{array}$ & $\begin{array}{l}-1.934 \\
(0.293)^{* * *}\end{array}$ & $\begin{array}{l}-2.415 \\
(0.540)^{* * *}\end{array}$ & $\begin{array}{l}-0.361 \\
(0.273)\end{array}$ & $\begin{array}{l}-0.949 \\
(0.508)\end{array}$ & $\begin{array}{l}-1.152 \\
(0.277)^{* * *}\end{array}$ & $\begin{array}{l}-2.199 \\
(0.526) * * *\end{array}$ & $\begin{array}{c}-0.430 \\
(0.338)\end{array}$ & $\begin{array}{l}-1.722 \\
(0.712) *\end{array}$ \\
\hline Observations & 985 & 929 & 985 & 929 & 985 & 929 & 985 & 929 & 985 & 929 & 985 & 929 \\
\hline Log likelihood & -486.735 & -450.796 & -632.063 & -563.740 & -624.310 & -563.941 & -643.015 & -588.318 & -653.026 & -609.616 & -376.759 & -318.703 \\
\hline $\begin{array}{l}\text { Akaike information } \\
\text { criterion }\end{array}$ & 983.470 & 921.592 & 1274.126 & 1147.480 & 1258.621 & 1147.881 & 1296.029 & 1196.636 & 1316.051 & 1239.232 & 763.518 & 657.405 \\
\hline
\end{tabular}

$* P<0.05, * P<0.01, * * P<0.001$. 
new forms of political participation (cf. Stolle and Micheletti, 2013; Copeland, 2014). This finding is very significant from a democratic point of view because it provides further evidence that the amelioration - and even reversal - of gender-based participatiory inequalities when new avenues of engagement are considered is solidifying as an empirical finding, providing women with a new voice. Age appears to be relevant for voting, consumerism, and volunteering. Although it is clear that being older means that one has a higher probability of turning out to vote, the two other modes also display a curvilinear relationship meaning that the probability of engaging in consumerist and protest participation acts increases with age, but is relatively low among both the younger and the older groups. Interestingly, and in line with recent studies conducted in the United States (Feezell, 2016), in our models restricted to resourcerelated determinants, age is unrelated to DNP and to volunteering. These findings provide some support for the argument that young people, a group traditionally less likely to be involved in politics through institutionalized participatory avenues, are finding opportunities for expressing their opinions through community-based and networked forms of participation (Zukin et al., 2006; Xenos et al., 2014).

Looking at the Akaike information criterion values makes it evident that, once attitudinal variables are added (and the number of cases is held constant at 929), every model as a whole fits significantly better than a model including only resources. Supporting postmaterialist values, theoretically a predictor of all - and not just new - forms of participation, only increases the probability of consumerist activities, while those identifying with the left also have a higher propensity to participate in such activities. Furthermore, people more satisfied with democracy have a higher propensity to vote. Our findings regarding the (non)-effect of postmaterialism are, interestingly, at odds with theoretical expectations (Norris, 2001) which would have precisely this type of online participation pursued by those with postmaterialist values (and extant empirical research about online participation confirms this - Theocharis, 2011a,b). However, as the coefficient shows the expected direction in all other models - and possible suspects for this finding (such as multicollinearity) have been ruled out - it is clear that DNP in Germany is not a form of engagement more likely to be pursued by those with postmaterialist values. As social media penetration is relatively low in Germany, one possible explanation is that the country's online public does not differ substantially with regards to value orientations: apparently, both materialists and postmaterialists are equaly likely to pursue the benefits of this additional avenue for political expression.

Being active in politics, our indicator aimed to show whether citizens who support this norm are just as likely to participate in old as they are to participate in new forms of engagement, is the only attitudinal variable that shows consistently statistically significant coefficients across all of our models. This finding is particularly interesting because it illustrates that new modes of participation share with well-established forms of political participation a 'core' predictor linked to the normative idea that being politically active is an aspect of good citizenship, indirectly showing that digitally networked acts are also perceived as political acts. We stress that, given the low-cost, 
self-expressive, communicative and, at first glance, impact-less nature of DNP (features that for some scholars and pundits render it non-political), it is not self-evident that citizens who believe that one should be active in politics would necessarily choose them as serious avenues for political engagement. This finding thus invites further research with more refined indicators about the link between citizens' normative perceptions of good citizenship and various forms of participation.

Figure 3 displays the predicted probabilities of participating in the different modes of participation examined in this study. Looking at the probabilities ${ }^{9}$ of participating in DNP, consumerist and voluntary acts, it becomes clear that those who believe that a good citizen should be active in politics have a higher propensity to engage in all three of the acts that lack an unambiguous political connotation - just as this is the case with the three classic modes of political participation (voting, institutionalized participation, and protest). ${ }^{10}$ In short, the findings support that new and expressive forms of political participation share, to a very largest extent, similar predictors to participatory acts traditionally considered and conceptualized as political.

With regards to the much-debated potential of DNP to ameliorate participatory inequalities, findings depicted in the full models display a relatively similar pattern to the findings presented by Schlozman et al. (2012: 532). Well-known socio-economic inequalities with regards to gender and education are both replicated for DNP while, in addition to those, having a higher income increases the propensity of engaging in all other participatory modes examined (see Appendix, Table A1 for model including income). That is, better-educated male individuals have a relatively higher probability to engage in DNP, just as it is the case with every other activity except from consumerist participation. Importantly, however, in our study agebased participatory inequalities do seem to be ameliorated in Germany as age is irrelevant for this type of participation.

\section{Conclusion}

Providing evidence from Europe's largest democracy, our findings enable us to draw three main conclusions - one methodological and two substantial. First, based on the conceptualization of political participation as a set of hierarchical ordered decision rules (van Deth, 2014), we developed a new instrument to measure the repertoire of political participation. This approach starts off the questionnaire with an extensive list of widely recognized forms of participation, which is then expanded with three digitally networked forms of participation. Crucially, an open-ended question is added at the very end offering the respondent the opportunity to mention activities that have not been covered by the previous items. The addition of the

\footnotetext{
${ }^{9}$ Predicted probabilities were calculated keeping all other variables constant at their mean (continuous variables - 0 was used for dummy variables).

${ }^{10}$ Given the distributional properties of our dependent variables we also performed sensitivity checks using count models (Poisson regressions). The results follow a very similar pattern (see Appendix Table A2).
} 

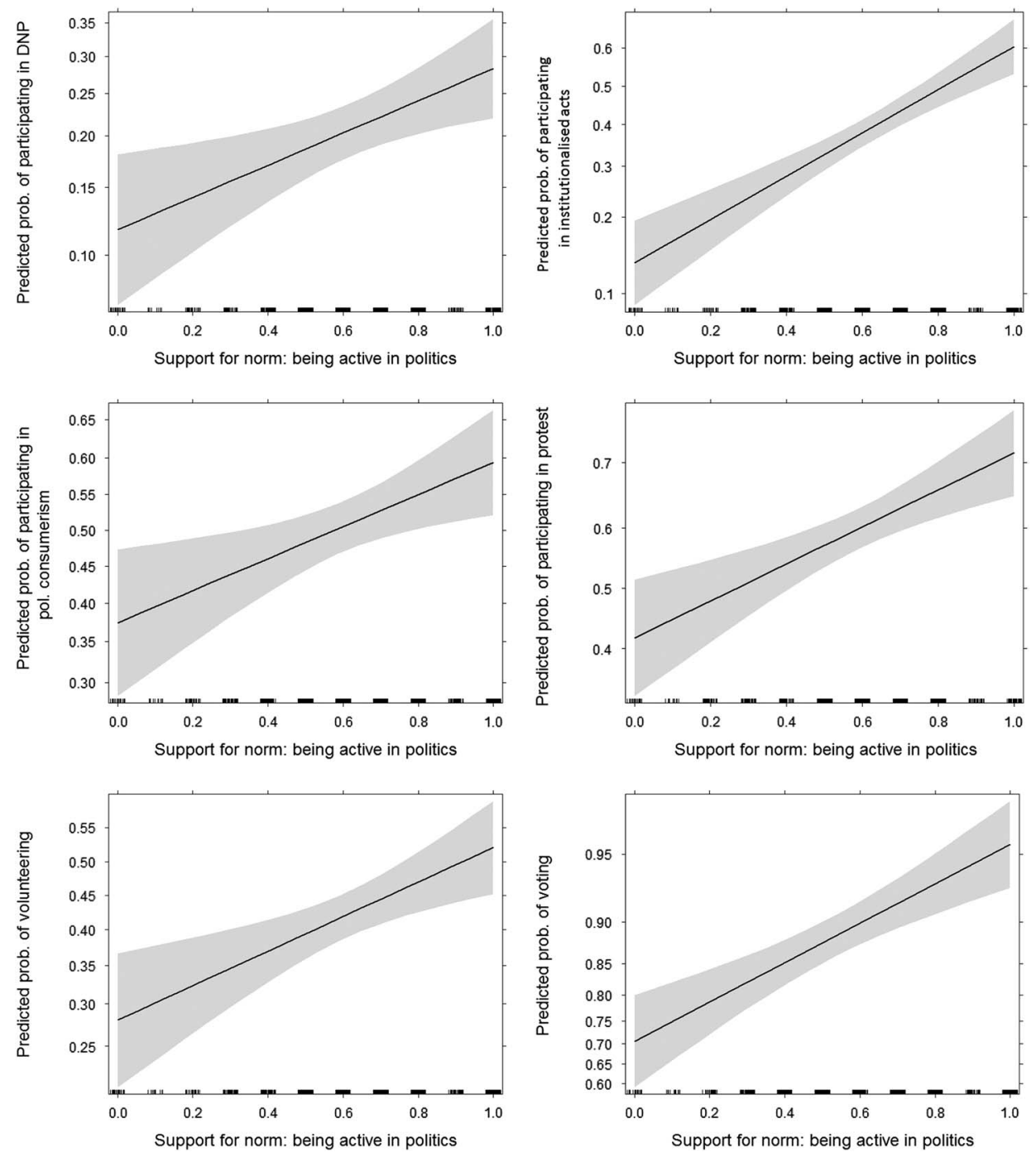

Figure 3 Support for norm 'being active in politics' and predicted probabilities of participating in six modes.

open-ended question revealed a wealth of activities and more than $5 \%$ of our respondents appear to have been engaged in them. These findings clearly show that our data collection strategy is understood correctly as a way to obtain information about activities that do not belong to the traditional repertoire of political participation. With the expected rise and further fragmentation of these expressive, creative, and individualized modes of participation our approach offers an encompassing method to study these developments systematically as parts of the expanding repertoire of political participation. 
A second, substantive conclusion is that although the open-ended question resulted in a long list of specific expressive, creative, and individualized modes of participation, these activities do not establish a new mode of participation, but are evidently expansions of the existing protest mode of political participation. This finding is, in fact, already suggested by many of the answers provided, which usually refer to involvement in 'actions' that are not very different from traditional protest activities. Yet, the inclusion of these new forms of participation in the protest dimension is remarkable because the unique character of these activities is frequently stressed (cf. McFarland, 2011). Apparently, protesters have a relatively high chance to use expressive, creative, or individualized forms and - vice versa people involved in these activities will likely also be involved in protest activities. In other words, these new forms of participation broaden the protest dimension, but do not establish a distinct mode of participation. Having successfully applied the procedure to one democratic polity, a basic requirement for future comparative research has been fulfilled, opening the door for further studying this phenomenon.

Our third conclusion is probably the most important one: digitally networked forms of participation do not establish an expansion of one of the available modes of participation. They create a new and distinct mode of participation well fitted within a general taxonomy of political participation. Moreover, the political nature of these activities is clearly underlined by the similarities in determinants of all modes of participation discerned. Yet, notably, DNP is the least popular of the six modes examined in this study. Even when considering the impressive rise of social media use over the last decade, and despite the low threshold for involvement offered by platforms such as Facebook and Twitter, DNP remains - in Europe's largest democracy at least - a marginal mode of participation. Do our findings also characterize the situation in other European countries? We believe that this point deserves further, comparative, research that can uncover some of the contextual factors that may be at play as it is very likely that our finding is associated with Germans' suspicious attitude towards social media in general, making Germany a distinctive case. Participation through digitally networked avenues may be far more prevalent among citizens of other Western societies where social media cultures are, as evidence from the United Kingdom, Italy, and Sweden shows, more vibrant and general online participation considerably higher (Xenos et al., 2014; Ekström and Östman, 2015; Valeriani and Vaccari, 2015). As an example, the picture in vibrant social media cultures, such as that of the United States, where social media have been adopted much earlier and have been integrated much deeper into daily life activities, is different. Based on a survey with a representative sample of the American population, the PEW Research Internet Project found that $40 \%$ of American adults have done at least one out of the eight digital media-based civic or political activities offered in the survey, including the three measured by this study (Smith, 2013). At the same time, according to the latest wave of the World Values Survey (2010-14), 34\% of Americans had signed a petition and attended a peaceful demonstration at least once during the last year, while almost $35 \%$ had joined a boycott. 
Most importantly, perhaps, as Schlozman et al. note for the United States (2012: 532), digital media elsewhere continue to develop with an astonishing pace and with unpredictable consequences not only for engaged citizenship. These media have been shown to be fertile venues for identity-, lifestyle-, personalized- and selfexpressive-driven citizen projects (Vromen et al., 2016), and many have argued that there is an increasing tendency of, especially young, citizens to pursue (political) projects of exactly such nature (Bang, 2009). It will thus not be surprising that, in the not too far future, these forms will become more popular among especially European publics, as new digital technologies become more integrated into political and social activities and daily life in general. Although it remains to be seen whether these participatory forms will negatively affect other forms of political engagement, our results show that new forms of participation are an addition to the already existing repertoire of participation, and one that is pursued alongside other activities - and not at the expense of other more traditional activities as it has often been claimed (Morozov, 2009; Gladwell, 2010). Future studies should pay particular attention into how citizens with different activist profiles and from different age groups may be combining different modes or forms in their repertoires of engagement (see e.g. Oser et al., 2013; Oser, 2016). Similarly, it is important to examine these processes dynamically, through longitudinal research designs, to observe the changing nature of repertoire adoption. We note that our findings also show that, aside from age-based inequalities, new forms probably do not yet change the wellknown divides in participation mainly associated with resource-related determinants. This said, as the evidence remains mixed (Krueger, 2006; Schlozman et al., 2012; Oser et al., 2013; Feezell, 2016), and contextual factors may have an important role to play, the jury is still out on whether digital media will eventually be able to ameliorate participatory inequalities.

Finally, our findings also imply that expressive, creative, and individualized modes of participation as well as DNP cannot and should not continue to remain outside the borders of large-scale comparative studies on political and social activities of citizens in advanced democracies. Scholars should continue to examine their rise through appropriate approaches and in different contexts. Especially in countries whereby trust in politics and institutions has eroded and institutionalized participation is seen with hostility (crisis-hit Greece is a case in point), new forms of participation will very likely be pursued by growing numbers of the population and in increasingly diverse ways. The central idea driving our study is that political participation is expanding, fundamentally altering what citizens understand as democratic engagement and politically active citizenship. The direct and most substantial, from a democratic point of view, consequence of this changing state of affairs, then, is that the way we assess the quality of democracy cannot remain unchanged. If the definition and meaning of democratic engagement is constantly redefined, researchers cannot stick to measures and taxonomies of political participation that proved their usefulness decades ago: the conclusions we draw about the quality of democracy depend on our definition of democratic engagement. 
Considering the increasing size of scholarship documenting the decline of traditional forms of political engagement, future studies based solely on dated definitions of political participation risk missing important democratic innovations and opportunities that evolve underneath, or in parallel with, the locus of what is traditionally considered as political (Dunleavy, 1990). ${ }^{11}$ Instead, we show that the concepts and tools for measuring new forms of participation can be updated based on the growing research that attempts to identify, document, conceptualize, and taxonomize these new forms of participation and democratic innovations more systematically (O’Toole et al., 2003; Smith, 2009; Amnå and Ekman, 2014; van Deth, 2014; Chou et al., 2015; Lee, 2015; Rowe, 2015; Theocharis, 2015). This development is not only important in terms of the analytical advantages stemming from being able to examine political participation in its multiple and oftentimes subtle facets. This is a time in which what citizen participation means has become a challenge to understand, not only for academics but also for policy makers (Coleman and Firmstone, 2014), and for citizens themselves. A broader understanding of democratic engagement, then, may hold the key for actors and organizations willing to craft, and evaluate the effectiveness of, strategies that can bring politics closer to the public, and make democracy more vibrant; an ambitious and important endeavour, especially in these challenging times.

\section{Acknowledgements}

The authors thank Christian Schnaudt, Kateřina Vráblíková, Peter Obert, Joost de Moor, Carolin Zorel, Sarah Perry, and Sebastian Popa for reading and commenting on earlier versions of the manuscript, as well as the participants of the 'Online and Offline Political Participation and Their Consequences for Democracy' panel in the 2015 Annual Meeting of the American Political Science Association for their comments and suggestions. The authors would also like to express their gratitude for the valuable comments and suggestions to the three anonymous reviewers of this journal.

\section{Supplementary material}

To view supplementary material for this article, please visit https://doi.org/10.1017/ S1755773916000230

\section{References}

Amnå, E. and J. Ekman (2014), 'Standby citizens: diverse faces of political passivity', European Political Science Review 6(2): 261-281.

Bang, H.P. (2009), “"Yes we can” idenity politics and project politics for a late-modern world', Urban Research and Practice 2(2): 117-137.

11 Observing both the effectivenes and rise of political consumerism in advanced industrialised democracies, Stolle and colleagues (2005, p.249) made a simliar point about the absence of discussions about this activity as a form of political participation. 
Bang, H.P. and E. Sørensen (1999), 'The everyday maker: a new challenge to democratic governance', Administrative Theory o Praxis 21(3): 325-341.

Bennett, L.W. and A. Segerberg (2013), The Logic of Connective Action: Digital Media and the Personalization of Contentious Politics, Cambridge: Cambridge University Press.

Brady, H. (1999), 'Political participation', in J.P. Robinson, P.R. Shaver and L.S. Wrightsman (eds). Measures of Political Attitudes, San Diego, CA: Academic Press, pp. 737-801.

Cain, B., R. Dalton and S. Scarrow (2003), Democracy Transformed? Expanding Political Opportunities in Advanced Industrial Democracies, Oxford: Oxford University Press.

Cammaerts, B., M. Bruter, S. Banaji, S. Harrison and N. Anstead (2014), 'The myth of youth apathy: young Europeans' critical attitudes toward democratic life', American Behavioral Scientist 58(5): 645-664.

Chou, M., J.-P. Gagnon and L. Pruitt (2015), 'Putting participation on stage: examining participatory theatre as an alternative site for political participation', Policy Studies 36(6): 607-622.

Coleman, S. and J. Firmstone (2014), 'Contested meanings of public engagement: exploring discourse and practice within a British city council', Media, Culture \& Society 36(6): 826-844.

Copeland, L. (2014), 'Conceptualizing political consumerism: how citizenship norms differentiate boycotting from buycotting', Political Studies 62(S1): 172-186.

Cronbach, L.J. and P.E. Meehl (1955), 'Construct validity in psychological tests', Psychological Bulletin 52(4): 281-302.

Dalton, R. (2008a), 'Citizenship norms and the expansion of political participation', Political Studies 56(1): $76-98$.

Dalton, R. (2008b), The Good Citizen: How a Younger Generation is Reshaping American Politics, Washington, DC: CQ Press.

Dalton, R. and M. Wattenberg (2000), Parties Without Partisans: Political Change in Advanced Industrial Democracies, Oxford: Oxford University Press.

Dunleavy, P. (1990), 'Mass political behaviour: is there more to learn?', Political Studies 38(3): 453-469.

Ekström, M. and J. Östman (2015), 'Information, interaction, and creative production: the effects of three forms of internet use on youth democratic engagement', New Media \& Society 42(6): 796-818.

Feezell, J.T. (2016), Predicting online political participation: the importance of selection bias and selective exposure in the online setting. Political Research Quarterly 69(3): 495-509.

Fox, S. (2013), 'Is it time to update the definition of political participation?', Parliamentary Affairs 67(2): 495-505.

Gabriel, O.W. and V. Völkl (2005), 'Politische und soziale partizipation', in O.W. Gabriel and E. Holtman (eds), Handbuch Politische System der Bundesrepublik Deutschland, München: Oldenbourg Verlag, pp. 523-573.

Gibson, R. and M. Cantijoch (2013), 'Conceptualizing and measuring participation in the age of the internet: is online political engagement really different to offline?', The Journal of Politics 75(3): 701-716.

Gladwell, M. (2010), 'Why the revolution will not be tweeted'. The New Yorker. Retrieved June 2016 from http://www.newyorker.com/magazine/2010/10/04/small-change-malcolm-gladwell.

Hempel, C.G. (1965), Aspects of Scientific Explanation and Other Essays in the Philosophy of Science, New York: Free Press.

Henn, M., M. Weinstein and S. Forrest (2005), 'Uninterested youth? Young people's attitudes towards party politics in Britain', Political Studies 53(3): 556-578.

Kaase, M. and A. Marsh (1979), 'Political action repertory: changes over time and a new typology', in S.H. Barnes, M. Kaase, et al. (eds), Political Action: Mass Participation in Five Western Democracies, Beverly Hills, CA: Sage, pp. 137-166.

Kahne, J., E. Middaugh and D. Allen (2015), 'Youth, new media, and the rise of participatory politics', in D. Allen, D. and J.S. Light (eds), From Voice to Influence: Understanding Citizenship in a Digital Age, Chicago, IL: Chicago University Press, pp. 35-58.

Kemp, S. (2014), 'European digital landscape 2014. We Are Social London'. Retrieved June 2016 from http://wearesocial.net/blog/2014/02/social-digital-mobile-europe-2014/.

Krueger, B. (2006), 'A comparison of conventional and internet political mobilization', American Political Research 34(6): 759-776. 
Lee, C. (2015), Do-It-Yourself Democracy: The Rise of the Public Engagement Industry, Oxford: Oxford University Press.

Li, Y. and D. Marsh (2008), 'New forms of political participation: searching for expert citizens and everyday makers', British Journal of Political Science 38: 247-272.

Macedo, S., Y. Alex-Assensoh, J. Berry, M. Brintnall, D.E. Campbell, L.R. Fraga, A. Fung, W.A. Galston, C.F. Karpowitz, M. Levi, M. Levinson, K. Lipsitz, R.G. Niemi, R.D. Putnam, W.M. Rahn, R. Reich, R.R. Rogers, T. Swanstorm and K. Cramer Walsh (2005), Democracy at Risk: How Political Choices Undermine Citizen Participation and What We Can Do About it, Washington, DC: Brookings Institution.

Marsh, D., T. O'Toole and S. Jones (2007), Young People and Politics in the UK: Apathy or Alienaton?, London: Palgrave, Basingstoke.

Marsh, D. and S. Akram (2015), 'Political participation and citizen engagement: beyond the mainstream', Policy Studies 36(6): 523-531.

McCaughey, M. and M.D. Ayers (2003), 'Introduction', in M. McCaughey and M.D. Ayers (eds), Cyberactivism: Online Activism in Theory and Practice, New York: Routledge, pp. 1-24.

McFarland, A.S. (2011), 'Why creative participation today?', in M. Micheletti and A.S. McFarland (eds), Creative Participation: Responsibility-Taking in the Political World, London: Paradigm Publishers, pp. 15-33.

Micheletti, M. and A.S. McFarland (2011), Creative Participation: Responsibility-Taking in the Political World, London: Paradigm Publishers.

Milbrath, L.W. and M.L. Goel (1977), Political Participation: How and Why Do People Get Involved in Politics, Chicago, IL: Rand McNally College Publishing Co.

Milner, H. (2013), 'Sociale media en de representatieve democratie', Res Publica 55: 107-117.

Morozov, E. (2009), 'The brave new world of slacktivism'. Foreign Policy. Retrieved June 2016 from http://neteffect.foreignpolicy.com/posts/2009/05/19/the_brave_new_world_of_slacktivism.

Morozov, E. (2013), 'The limits of technology in an imperfect world, London'. Retrieved June 2016 from http://www.chathamhouse.org/sites/files/chathamhouse/public/Meetings/MeetingTranscripts/180313 MorozovQA.pdf.

Norris, P. (2001), Digital Divide: Civic Engagement, Information Poverty, and the Internet Worldwide, Cambridge: Cambridge University Press.

Norris, P. (2002), Democratic Phoenix: Reinventing Political Activism, Cambridge: Cambridge University Press.

Oser, J. (2016), Assessing how participators combine acts in their "political tool kits": a person-centered measurement approach for analyzing citizen participation. Social Indicators Research, http:/link. springer.com/article/10.1007/s11205-016-1364-8.

Oser, J., M. Hooghe and S. Marien (2013), 'Is online participation distinct from offline participation? A latent class analysis of participation types and their stratification', Political Research Quarterly 66(1): 91-101.

O'Toole, T., D. Marsh and S. Jones (2003), 'Political literacy cuts both ways: the politics of non-participation among young people', The Political Quarterly 74(3): 349-360.

Parry, G., G. Moyser and N. Day (1992), Political Participation in Britain, Cambridge: Cambridge University Press.

Pharr, S. and R. Putnam (2000), Disaffected Democracies: What's Troubling the Trilateral Countries?, Princeton, NJ: Princeton University Press.

Rowe, P. (2015), 'MamaBakers as everyday makers: the political is personal', Policy Studies 36(6): 623-639.

Schlozman, K.L., S. Verba and H.E. Brady (2012), The Unheavenly Chorus: Unequal Political Voice and the Broken Promise of American Democracy, Princeton, NJ: Princeton University Press.

Sloam, J. (2014), 'New voice, less equal: the civic and political engagement of young people in the United States and Europe', Comparative Political Studies 47(5): 663-688.

Smith, G. (2009), Democratic Innovations: Designing Institutions for Citizen Participation, Cambridge: Cambridge University Press.

Smith, A. (2013), 'Civic engagement in the digital age'. Retrieved June 2016 from http://pewinternet.org/ Reports/2013/Civic-Engagement.aspx. 
Stoddart, K. (2014), 'How to make a seedbomb'. The Guardian. Retrieved June 2016 from http://www. theguardian.com/lifeandstyle/gardening-blog/video/2014/aug/01/how-to-make-a-seed-bomb-video.

Stolle, D. and M. Micheletti (2013), Political Consumerism. Global Responsibility in Action, Cambridge: Cambridge University Press.

Stolle, D., M. Hooghe and M. Micheletti (2005), 'Politics in the supermarket: political consumerism as a form of political participation', International Political Science Review 26(3): 245-269.

Teorell, J., M. Torcal and J.R. Montero (2007), 'Political participation: mapping the terrain', in J.W. van Deth, J.R. Montero and A. Westholm (eds), Citizenship and Involvement in European Democracies: A Comparative Analysis, London: Routledge, pp. 334-357.

Theocharis, Y. (2011a), 'The influence of postmaterialist orientations on young British people's offline and online political participation', Representation 47(4): 435-455.

Theocharis, Y. (2011b), 'Young people, political participation and online postmaterialism in Greece', New Media \& Society 13(2): 203-223.

Theocharis, Y. (2015), 'The conceptualization of digitally networked participation', Social Media + Society 1(2): 1-14.

Tilly, C. (1995), Popular Contention in Great Britain 1758-1834, Cambridge, MA: Harvard University Press.

Valeriani, A. and C. Vaccari (2015), Accidental exposure to politics on social media as online participation equalizer in Germany, Italy, and the United Kingdom. New Media \& Society, 18(9): 1857-1874.

van Deth, J.W. (2001), 'Studying political participation. Towards a theory of everything?'. Paper presented at the Joint Session of Workshops of the European Consortium for Political Research, 6-11 April 2001, Grenoble, France.

van Deth, J.W. (2014), 'A conceptual map of political participation', Acta Politica 49(3): 349-367.

Van Laer, J. and P. Van Aelst (2010), 'Internet and social movement action repertoires', Information, Communication \& Society 13(8): 1146-1171.

Verba, S. and N.H. Nie (1972), Participation in America: Political Democracy and Social Equality, Chicago, IL: University of Chicago Press.

Verba, S., K.L. Schlozman and H.E. Brady (1995), Voice and Equality. Civic Voluntarism in American Politics, Cambridge, MA and London, England: Harvard University Press.

Vromen, A., B.D. Loader, M. Xenos and F. Bailo (2016), Everyday making through Facebook engagement: young citizens' political interactions in Australia, the United Kingdom and the United States. Political Studies, 64(3): 513-533.

Welzel, C. (2013), Freedom Rising: Human Empowerment and the Quest for Emancipation, New York: Cambridge University Press.

Xenos, M., A. Vromen and B. Loader (2014), 'The great equalizer? Patterns of social media use and youth political engagement in three advanced democracies', Information, Communication \& Society 17(2): 151-167.

Young, I.M. (1989), 'Polity and group difference: a critique of the ideal of universal citizenship', Ethics 99: 250-274.

Zuckerman, E. (2014), 'New media, new civics?', Policy \& Internet 6(2): 151-168.

Zukin, C., S. Keeter, M. Andolina, K. Jenkins and M.X. Delli Xarpini (2006), A New Engagement? Political Participation, Civic Life, and the Changing American Citizen, Oxford: Oxford University Press. 